\title{
LIST OF AUTHORS - FORESTRY CHRONICLE, VOLUME 68, 1992
}

Aird, Paul L. Images of conservation education: Reconciling vision with reality Aird, Paul L. The forestry potlach

Aldred, A. H. - See Hall, R. J.

Armleder, H. M. and R. J. Dawson. Logging on mule deer winter range: An integrated management approach

Ayling, R. D. Changing perspectives on the demands on tropical forests

Balisky, A. C. - See Burton, P. J. et al

Baskent, E. Z. - See Jordan, G. A.

Beaudoin, Roger. Observations sur la tolérance aux embruns salins d'espèces ligneuses en plantation aux abords des autoroutes

Béland, Martin et Jean Lapierre. Influence du gauchissement de semis d'épinette noire (Picea mariana (Mill.) B.S.P. produits en serre sur leur performance en plantation

Bélanger, L., Y. Bergeron et C. Camiré. Ecological land survey in Quebec

Bergeron, Jean-François, Jean-Pierre Saucier, André Robitaille and Denis Robert. Québec

forest ecological classification program

Bergeron, Y. - See Bélanger, L. et al

Binkley, Clark S. and Susan B. Watts. The

status of forestry research in British Columbia

Boswell, Ted. The economic strength of our forest industy. A question of: Process, Pachyderms and paradigms

Bousquet, Jean - See Li, Peng et al

Bowling, Colin and Vincent Zelazny. Forest site classification in New Brunswick

Boyle, T. J. B. Biodiversity of Canadian forests:

Current status and future challenges

Boyle, Biodiversity research - Introduction

Brown, Kenneth M. - See Van Damme, Laird

Burton, P. J., A. C. Balisky, L. P. Coward, S.

G. Cumming and D. D. Kneeshaw. The value of managing for diversity

Camiré, C. - See Bélanger, L. et al

Carlson, Michael. Municipal effluent irrigation of

fast-growing hybrid poplar plantations near

Vernon, British Columbia

Carvill, K. M. - See Weetman, G. F. et al

Clark, Robin - See Aird, Paul L.

Cook, B. A. Forest property taxation in New

Brunswick: A comment

Coons, Clarence F. The Alligator steam warping tug

Corns, Ian G. W. Forest site classification in

Alberta: Its evolution and present status

Coward, L. P. - See Burton, P. J. et al

Cumming, H. G. Woodland caribou: Facts for forest managers

Cumming, S. G. - See Burton, P. J. et al

Dawson, R. J. - See Armleder, H. M.

El-Kassaby, Y. A. Domestication and genetic

diversity - Should we be concerned?
598

664

142

476

225

503

496

365

53

42

730

665

709
Fletcher, Chris - See M'Gonigle, Michael et al

Fowler, D. P. and J. A. Loo-Dinkins. Breeding strategies in a changing climate and implications for biodiversity

Fulford, Robert. The forest and Canadian culture Gagnon, Réjean - See Guay, Régent et al Greenwood, Richard - See LeMay, Valerie M. et al

Griss, Paul. A forester's guide to the environmental movement

Guay, Régent, Réjean Gagnon and Hubert

Morin. A new automatic and interactive tree ring measurement system based on a line scan camera Gunton, Thomas. - See M'Gonigle, Michael et al

Hall, R. J. and A. H. Aldred. Forest regeneration appraisal with large-scale aerial photographs Helson, Blair. Naturally derived insecticides:

Prospects for forestry use

Hsieh, Ling. Origin and distribution of Ginko biloba

Johnston, Steven. North/south forest ethics and trade in tropical forest products

Jordan, G. A. and E. Z. Baskent. A case study in spatial wood supply analysis windbreaks

Klinka, K. - See MacKinnon, A. et al Kneeshaw, D. D. - See Burton, P. J. et al Kozak, Antal and Stephen A. Y. Omule. Estimating stump volume, stump inside bark diameter and diameter at breast height from stump measurements

Krugman, Stanley L. Biotechnology and biodiversity - the interrelationships Laird, C. E. - See Weetman, G. F. et al Lapierre, Jean - See Béland Martin LeMay, Valerie M., Richard Greenwood, Peter L. Marshall, Margaret Penner, and Doug Walker. Status of growth and yield research: 1991 joint technical session of forest measurements, tree improvement and silviculture, and forest management working groups LeMay, Valerie M. - See Marshall Peter L. et al

Li, Peng, John Mackay and Jean Bousquet.

Genetic diversity in Canadian hardwoods: Implications for conservation

Licht, Louis A. Salicaceae family trees in sus-

tainable agroecosystems

Loo-Dinkins, J.A. See Fowler, D. P.

Mackay, John - See Li, Peng et al

MacKinnon, A., D. Meidinger and K. Klinka.

Use of biogeoclimatic ecosystem classification system in British Columbia

MacKnight, Doug - See M'Gonigle, Michael et al 
Marshall, Peter L. - See LeMay, Valerie M. et al

Marshall, Peter L., Valerie M. LeMay and Albert Nussbaum. Sample size adjustment to reduce the probability of exceeding a specified confidence interval width

Martell, David L. Forestry research

implementation

McAllister, Murdoch - See M'Gonigle, Michael et al

Meades, W. J. and B. A. Roberts. A review of forest site classification activities in Newfoundland and Labrador

Meidinger, D. - See MacKinnon, A. et al

M'Gonigle, Michael, Thomas Gunton, Chris

Fletcher, Murdoch McAllister and Doug

MacKnight. Comprehensive wilderness protection in British Columbia: An economic impact assessment

Morin, Hubert - See Guay, Régent et al

Moss, Ian S. Foresters' ethics

Mosseler, A. Life history and genetic diversity in red pine: Implications for gene conservation in forestry

Namkoong, Gene. Biodiversity - Issues in

genetics, forestry and ethics

Nussbaum, Albert - See Marshall, Peter L. et al

Newnham, R. M. Cluster analysis: An application in forest management planning

Oberle Federal forestry initiatives

Omule, Stephen A. Y. - See Kozak, Antal

Oswald, E. T. Forest site classification activities

in Northern Canada

Owusu-Gyima, P. K. and D. N. Roy. Pulpmill

pollution and public perception

Penner, Margaret - See LeMay, Valerie M. et al

Prasad, R. - See Wall, R. E. et al

Robert, Denis - See Bergeron, Jean-François

et al

Roberts, B. A. - See Meades, W. J.

Robitaille, André - See Bergeron, Jean-François et al

Rose, Steven. GIS at Sir Sandford Fleming

College

Rowe, J. S. Prologue (Site classification)

Rowe, J. Stan. The ecosystem approach to forestland management
Roy, D. N. - See Owusu-Gyima, P. K.

Saucier, Jean-Pierre - See Bergeron, Jean-

François et al

Schwartz, Mark. Potential effects of global climate change on the biodiversity of plants

462

Shamoun, S. F. See Wall, R. E. et al

736

Sims, R. A. Introduction (Site classification)

Sims, R. A. and P. Uhlig. The current status of forest site classification in Ontario

357 Strang, R. M. Douglas-fir (Pseudotsuga menziesii) and the Scots connection

Sutton, R. F. White spruce (Picea glauca

25 [Moench] Voss): stagnating boreal old-field plan-

100 tations unresponsive to fertilization and weed control

Taylor, S. W. - See Weber, M. G.

Turgeon, Jean J. Status of research on the development of management tactics and strategies

for the spruce bud moth in white spruce

plantations

Uhlig, P. - See Sims, R. A.

Van Damme, Laird and Kenneth M. Brown.

The Ontario Advanced Forestry Program

701 Van Sickle, G. A. A review of innovations in disease and insect management and control

Walker, Doug - See LeMay, Valerie M. et al

Wall, R. E., R. Prasad and S. F. Shamoun. The development and potential role of mycoherbicides

Watts, Susan B. - See Binkley, Clark S.

623 Weber, M. G. and S. W. Taylor. The use of prescribed fire in the management of Canada's

94 forested land

Weetman, G. F., K. M. Carvill and C. E.

Laird. Addressing the advanced education needs of silviculturists: The Silviculture Institute of British Columbia

Wells, Russell E. User information needs for forest management site classification in Manitoba Williams, J. T. International aspects of biodiversity

53 Yang, R-C. and Frances C. Yeh. Genetic consequences of in situ and ex situ conservation of

Yeh, Frances C. - See Yang, R-C.

Yeh, Frances C. - See Boyle, Tim

\title{
Quebec and Ontario Paper Company Ltd.
}

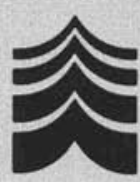

\author{
A CIF/IFC Corporate Sustaining Member
}

